\title{
DAMPAK KEPEMIMPINAN DIRI TENAGA OPERASIONAL TERHADAP PENINGKATAN KINERJA (SURVEY PADA PT. TRANSPOWER MARINE, TBK 2015)
}

\author{
Andi Prasetiawan \\ Dosen Program Studi KALK PIP Semarang
}

\begin{abstract}
The research aim to now relation leadership of x'self with operational energy performance In this research, target population (target) is all PT. Transpower Marine,Tbk employees while population reached by is all PT. Transpower Marine operational energy, Tbk in this case counted $40 \mathrm{crew}$ man. Research Sampel of is set in this research is saturated sampel counted 40 People. Technique analyse data use regresi analysis and simple correlation.

Pursuant to examination of conducted research hypothesis, hence this research indicate that fourthly of hypothesis which is raised in this research (H1) accepted and refuse hypothesis zero (Ho). (1) There are positive relation between leadership of $x$ 'self $(X)$ with operational energy performance,.
\end{abstract}

\section{Keywords: Leadership of x'self, performance, operational}

\section{PENDAHULUAN}

Sumber daya manusia merupakan faktor terpenting dalam setiap kegiatan perusahaan, karena bagaimanapun canggihnya teknologi yang digunakan tanpa didukung oleh manusia sebagai pelaksana kegiatan operasionalnya tidak akan mampu menghasilkan output sesuai yang diharapkan.

Dengan demikian, kualitas SDM pada setiap perusahaan harus ditingkatkan secara terus menerus agar mampu bersaing dan beradaptasi dengan percepatan kemajuan perusahaan lainnya. Upaya peningkatan kualitas SDM ini terkait erat dengan modal yang dimiliki manusianya. Melalui modal manusia ini individu-individu dalam organisasi akan mampu mengembangkan strategi-strategi baru dalam menghadapi organisasi pesaing, sehingga tetap dapat menjadi yang terdepan dalam bidang bisnis yang digarapnya. Kekuatan daya saing dalam bisnis dewasa ini sangat perlu didukung oleh keberadaan SDM yang andal yang memiliki modal kemampuan yang tinggi.

Pada 2010, seluruh perdagangan dalam negeri dari tiga belas jenis komoditas harus dibawa oleh perkapalan yang berbendera nasional. Salah satu komoditas yang terkena asas cabotage adalah batubara. Batubara adalah sumber daya alam yang saat ini berpengaruh cukup besar terhadap perekonomian Indonesia. Cadangan batubara Indonesia yang tercatat di Departemen Energi dan Sumber Daya Mineral adalah 19 miliar ton, termasuk sepuluh besar di dunia. Demikian juga jumlah produksi tahun 2008 mencapai 230 juta ton. Indonesia juga menjadi Negara pengekspor batubara terbesar kedua di dunia, setelah Australia sekitar 160 juta ton pada 2008.

Dengan kondisi di atas, tentu tidak mengherankan kalau batubara memberikan sumbangan devisa negara yang cukup besar setelah pajak dan migas. Penerimaan Negara dari batubara pada 2008 sebesar Rp 10,2 triliun dan diperkirakan meningkat menjadi Rp 20 triliun pada 2009. Namun sayang, penerimaan negara dari bidang transportasi laut komoditas batubara tersebut belum optimal. Perlu diketahui, dari 160 juta ton batubara yang diekspor Indonesia ternyata hanya 10 persen yang angkutan lautnya menggunakan perusahaan angkutan nasional. Sementara itu, di dalam perdagangan domestik hanya 60 persen dari 40 juta ton batubara yang dikonsumsi dalam negeri (domestik), selebihnya diekspor. 
Dalam peluang ini PT. Transpower Marine, Tbk yang mulai didirikan pada tahun 2005 terus melanjutkan ekspansi dalam bidang transportasi laut batubara dan angkutan pemindah muatan di laut dengan mengunakan armada kapal tunda dan tongkang serta crane apung (Floating Crane). Sejak awal berdirinya, Perusahaan telah menunjukkan potensi besar di industri pelayaran nasional. Armada Perusahaan berupa kapal tunda, tongkang dan crane barge dengan lisensi Surat Izin Usaha Perusahaan Angkutan Laut dari Kementrian Perhubungan Direktorat Jenderal Perhubungan Laut dengan No.BXXV89/AL58 tanggal 28 Februari 2005 bergerak dan membawa Perusahaan pada pencapaianpencapaian positif termasuk kontrak jangka panjang dengan salah satu perusahaan tambang terbesar di Indonesia yaitu PT. Jorong Barutama Greston dan perusahaanperusahaan raksasa lainnya.

Setelah beberapa tahun beroperasi dan mengimplementasikan strategi terbaiknya dengan armada yang disewa dari pihak ketiga, Perusahaan akhirnya mendapatkan kepercayaan dari bank untuk melakukan pengadaan armada kapal sendiri. Tercatat sejak 2007, perusahaan memiliki 8 (delapan) kapal tunda dan 7 (tujuh) kapal tongkang. Jumlah tersebut terus meningkat mencapai 2 (dua) crane barge, 37 (tiga puluh tujuh) kapal tunda dan 34 (tiga puluh empat) kapal tongkang per Desember 2014. Demi memenuhi tingginya permintaan pasar baik di lingkup nasional dan internasional, perusahaan terus mengerahkan armada terbaiknya dan mempertahankan predikat sebagai perusahaan yang agresif dan ekspansif.

Namun dalam melakukan kegiatan operasinalnya PT. Transpower Marine, Tbk pun harus mengalami permasalahan dalam hal kinerja di aspek sumber daya manusia yang mengakibatkan menurunnya kinerja dalam operasional. Beberapa contoh masalah teknis mengenai SDM adalah sebagai berikut:

(1) Melambatnya kinerja pemuatan di armada crane apung dalam kegiatan
Trans-shipment (pemindah muatan di atas laut melalui lebih dari atau 2 moda transportasi laut)

(2) Terjadi keterlambatan keberangkatan kapal tunda dan tongkang (delay) di pelabuhan bongkar ataupun muat

(3) Kurang optimalnya muatan yang bisa diangkut di atas kapal tunda dan tongkang dalam hal direct shipment maupun transshipment

(4) Besarnya biaya (sekitar 10-70 juta rupiah) pada setiap keagenan kapal di pelabuhan muat ataupun bongkar untuk kapal tunda dan tongkang

(5) Ketidakpuasan pelanggan dalam hal pengiriman muatan berdasarkan survei kepuasan pelanggan

(6) Kurangnya motivasi karyawan (SDM) dalam setiap kegiatan operasional yang terlihat dari menurunnya kinerja beberapa tahun belakangan

Beberapa permasalahan di PT. Transpower Marine, Tbk tersebut di atas memberi gambaran bahwa pelayanan pengiriman muatan batubara belum berjalan dengan baik akan berpengaruh pada distribusi muatan batubara di Indonesia karena berdasarkan data 2014 pengiriman batubara ekspor dan pemakaian dalam negeri akan mengalami kenaikan mencapai 190 Juta ton (Sumber: http://www.indo-nesiainvestments.com/id/ bisnis/komoditas/batu-bara/item236). Dan pada tahun selanjutnya diprediksi kenaikan dalam pemakaian batubara untuk dalam negeri dan penurunan untuk ekspor.

Peningkatan pelayanan PT. Transpower Marine, Tbk merupakan hal yang sangat penting dilakukan untuk meningkatkan daya saing angkutan batubara dalam negeri yang akan berimbas pada peningkatan daya saing distribusi batubara Indonesia. Karena pelayanan pengiriman muatan merupakan pelayanan jasa logistik maka pengukuran dan penilaian oleh konsumen perlu dilakukan untuk mengindentifikasi penilaian konsumen /pengguna jasa angkutan.

Berdasarkan uraian tersebut di atas PT. Transpower Marine, Tbk perlu 
memper-hatikan kinerja karyawan dengan fokus pada dampak kepemimpinan diri tenaga operasional terhadap peningkatan kinerja.

\section{METODE PENELITIAN}

\section{Populasi dan Sampling}

Populasi adalah jumlah keseluruhan dari unit analisis yang ciri-cirinya akan diduga. Populasi dapat dibedakan antara populasi sasaran (target) dan populasi terjangkau. Dalam penelitian ini, populasi sasaran (target) adalah seluruh karyawan PT. Transpower Marine, Tbk sedangkan populasi terjangkau adalah seluruh tenaga operasional PT. Transpower Marine, Tbk dalam hal ini sebanyak 40 awak kapal.

Sampel penelitian yang ditetapkan dalam penelitian ini adalah sampel jenuh sebanyak 40 orang. Teknik ini dilakukan dengan tetap memperhatikan dan mempertimbangkan aspek representasi dari kesamaan karakteristik populasi.

\section{Instrumen Penelitian}

\section{Variabel Kinerja karyawan (Y)}

a. Definisi Konseptual

Kinerja karyawan adalah tingkat pencapaian hasil kerja karyawan yang diukur dengan membandingkan antara pelaksanaan nyata dengan standar kerja dengan indikator-indikator yaitu: (1) tanggung jawab; (2) ketuntasan tugas; (3) pelaksanaan kerja; (4) prestasi kerja; dan (5) umpan balik.

b. Definisi Operasional

Kinerja karyawan adalah skor total dari hasi penilai terhadap tingkat pencapaian hasil kerja karyawan yang diukur dengan membandingkan antara pelaksanaan nyata dengan standar kerja meliputi pengukuran yaitu: tanggung jawab; (2) ketuntasan tugas; (3) pelaksanaan kerja; (4) prestasi kerja; dan (5) umpan balik, dengan menggunakan skala Likert terdiri lima opsi yaitu; $a=$ sangat setuju, $b=$ setuju, $\mathrm{c}=$ kurang setuju, $\mathrm{d}=$ tidak setuju, dan $\mathrm{e}=$ sangat tidak setuju dan skor setiap pernyataan positif: $\mathrm{a}=5, \mathrm{~b}=4, \mathrm{c}=3, \mathrm{~d}$
$=2$, dan $\mathrm{e}=1$; sedangkan pernyataan negatif: $\mathrm{a}=1, \mathrm{~b}=2, \mathrm{c}=3, \mathrm{~d}=4$, dan $\mathrm{e}$ $=5$.

\section{Variabel Kepemimpinan Diri (X)}

a. Definisi Konseptual

Kepemimpinan diri adalah kesanggupan karyawan untuk mempengaruhi dan meningkatkan perilakunya dan memiliki tanggung jawab dan mampu mengatur waktu secara efektif, memonitor perilaku sendiri, dan menerima konsekuensi dari perilaku tersebut.

b. Definisi Operasional

Kepemimpinan diri adalah kesanggupan untuk mempengaruhi dan meningkatkan perilakunya dan memiliki tanggung jawab dan mampu mengatur waktu secara efektif, memonitor perilaku sendiri, dan menerima konsekuensi dari perilaku tersebut, yang mengukur aspek; penguatan diri, pengamatan diri, pengharapan diri, penerapan sasaran diri; kritik diri (self-critism), dan mendukung anggota kelompok, dengan menggunakan skala Likert terdiri lima opsi yaitu; $a=$ sangat setuju, $b=$ setuju, $\mathrm{c}=$ kurang setuju, $\mathrm{d}=$ tidak setuju, dan $\mathrm{e}=$ sangat tidak setuju dan skor setiap pernyataan positif : $\mathrm{a}=5, \mathrm{~b}=4, \mathrm{c}=3, \mathrm{~d}$ $=2$, dan $\mathrm{e}=1$; sedangkan pernyataan negatif: $\mathrm{a}=1, \mathrm{~b}=2, \mathrm{c}=3, \mathrm{~d}=4$, dan $\mathrm{e}$ $=5$

\section{Teknik Analisis Data}

Data yang terkumpul dilakukan analisis dengan menggunakan statistik sebagai berikut; (1) deskripsi data yang meliputi rata-rata, rentangan, standar deviasi, median, modus dan dilengkapi dengan frekuensi dan histogram, (2) pengujian persyaratan analisis yaitu meliputi pengujian normalitas dan uji homogenitas varians, dan (3) pengujian hipotesis dilakukan dengan menggunakan analisis regresi dan korelasi sederhana untuk masing variabel bebas terhadap variabel terikat, dan regresi ganda untuk seluruh variabel 
bebas dengan variabel terikat, serta korelasi ganda dan parsial.

\section{HASIL DAN DISKUSI}

\section{Uji Homogenitas Varians}

Uji homogenitas varians dimaksudkan untuk menguji homogenitas varians kelompok skor masing-masing variabel yang menggunakan distribusi Chi Kuadrat. Kriteria yang digunakan adalah terima $\mathrm{H}_{0}$ jika $\chi^{2}$ hitung lebih kecil atau sama dengan $\chi^{2}$-tabel pada taraf signifikansi $\alpha=0,05$.

\section{1) Pengujian Homogenitas Varians $Y$}

Hasil perhitungan untuk pengujian homogenitas varians $\mathrm{Y}$ atas $\mathrm{X}_{1}$ diperoleh $\chi^{2}$ hitung $=22,05$ dan $\chi^{2}$ tabel $=43,8$ pada taraf $\propto=0,05$ (lihat lampiran 4). Karena $\chi^{2}$ hitung $=22,05<$ $\chi^{2}$ tabel $=43,8$ maka $\mathrm{H}_{0}$ diterima dan $\mathrm{H}_{1}$ ditolak, dengan demikian dapat disimpulkan bahwa varians kelompok $\mathrm{Y}$ adalah homogen.

\section{2) Pengujian Homogenitas Varians $X$}

Hasil perhitungan untuk pengujian homogenitas varians $\mathrm{X}$ diperoleh $\chi^{2}$ hitung $=20$ dan $\cdot \chi^{2}$ tabel $=43,8$ pada $\propto=0,05$ (lihat lampiran 4). Karena $\chi 2$ hitung $=20<\chi 2$ tabel $=43,8$, maka $\mathrm{H} 0$ diterima dan H1 ditolak, dengan demikian dapat disimpulkan bahwa varians kelompok $\mathrm{X}$ adalah homogen.

Keseluruhan hasil uji homogenitas varians seperti telah disajikan di atas dirangkum dalam tabel sebagai berikut:

\begin{tabular}{|c|c|c|c|c|}
\hline \multirow[b]{2}{*}{$\begin{array}{c}\text { Varians } \\
\text { kelompok }\end{array}$} & & arians & & \\
\hline & $D k$ & $\begin{array}{c}\chi^{2} \\
\text { hitung }\end{array}$ & $\begin{array}{c}\chi^{2} \\
\text { tabel } \\
\alpha= \\
0,05\end{array}$ & Keterangan \\
\hline$Y$ & 16 & 22,05 & 43,8 & Homogen \\
\hline$X$ & 14 & 20,00 & 43,8 & Homogen \\
\hline
\end{tabular}

Hasil perhitungan uji homogenitas varians $Y$ diperoleh $\chi^{2}$ hitung $=22,05<\chi^{2}$ tabel $=43,8$ maka $\mathrm{H}_{0}$ diterima dan $\mathrm{H}_{1}$ ditolak, dan perhitungan uji homogenitas varians $\mathrm{X}$ diperoleh $\chi^{2}$ hitung $=20<\chi^{2}$ tabel $=43,8$, maka $\mathrm{H}_{0}$ diterima dan $\mathrm{H}_{1}$ ditolak. Dengan demikian dapat disimpulkan bahwa varians kelompok skor $\mathrm{Y}$ dan $\mathrm{X}$ adalah homogen.

\section{Pengujian Hipotesis}

Pengujian persyaratan analisis menunjukkan bahwa skor tiap variabel penelitian telah memenuhi persyaratan untuk dilakukan pengujian statistik lebih lanjut. Berikut ini akan disajikan pengujian hipotesis penelitian.

\section{Hubungan antara Kepemimpinan Diri}

\section{$\left(\mathrm{X}_{2}\right)$ dengan Kinerja tenaga operasional (Y)}

Hipotesis menyatakan terdapat hubungan positif antara kepemimpinan diri $\left(\mathrm{X}_{2}\right)$ dengan kinerja tenaga operasional (Y). Hubungan antara kepemimpinan diri(X) dengan kinerja tenaga operasional (Y) ditunjukkan dengan persamaan regresi $\hat{Y}=40.197+$ 0.751X. Dari harga-harga JK yang didapat, disusun dalam daftar analisis varians yang disingkat dengan nama ANOVA untuk regresi dan linear sederhana.

Berdasarkan hasil uji signifikansi dan linearitas di atas menunjukkan bahwa harga F-hitung diperoleh sebesar 28,427 sedangkan harga $\mathrm{F}$ tabel dengan $\mathrm{dk}$ pembilang 1 dan $\mathrm{dk}$ penyebut 38 pada taraf signifikansi 0,01 sebesar 7.12. Ternyata harga F-hitung lebih besar dari harga F-tabel, maka dapat disimpulkan bahwa koefisien arah regresi $\mathrm{Y}$ atas $\mathrm{X}_{2}$ "sangat signifikan" pada taraf signifikansi 0,01 .

Harga F-tuna cocok hasil perhitungan diperoleh sebesar 1,031 sedangkan harga F- tabel dengan dk pembilang 13 dan dk penyebut 25 pada taraf signifikansi 0,05 sebesar 2,38. Ternyata harga $F_{\text {tc(hitung) }}$ lebih kecil dari harga $\mathrm{F}_{\text {tabel, }}$ maka dapat disimpulkan bahwa bentuk regresi $\mathrm{Y}$ atas $\mathrm{X}_{2}$ adalah "linear". 
Untuk mengetahui seberapa besar kontribusi variabel kepemimpinan diri tenaga operasional $\left(\mathrm{X}_{2}\right)$ secara keseluruhan dalam memprediksi variabel kinerja tenaga operasional (Y) maka diterapkan teknik analisis regresi sederhana. Hasil perhitungan regresi sederhana dapat dilihat sebagai berikut:

Dari hasil penelitian dapat diketahui bahwa secara signifikan dapat untuk memprediksi kinerja tenaga operasional. Hal ini terbukti bahwa harga $\mathrm{F}$ hitung sebesar 28,688 dari $\mathrm{F}$ tabel $=7,12$ pada taraf signifikansi 0,01 .

Koefisien korelasi determinasi $\left(\mathrm{r}^{2}\right)$ sebesar 0,430 menunjukan bahwa pengaruh atau kontribusi kepemimpinan diri terhadap kinerja tenaga operasional adalah sebesar $43 \%$ sedangkan sisanya $57 \%$ dipengaruhi oleh variabel lain.

\section{KESIMPULAN}

Berdasarkan pengujian hipotesis penelitian yang dilakukan, maka penelitian ini menunjukkan bahwa keempat hipotesis yang diajukan dalam penelitian ini terdapat hubungan positif antara kepemimpinan diri (X) dengan kinerja tenaga operasional. Berikut ini akan diuraikan secara rincian kesimpulan dari hasil penelitian yang meliputi:

Kepemimpinan diri (X) mempunyai hubungan positif dengan kinerja tenaga operasional (Y) namun dilakukan pengontrolan terhadap variabel bebas lain baik secara sendiri-sendiri maupun secara bersama-sama tidak memberikan pengaruh. Hal ini menunjukkan bahwa kepemimpinan diri (X) tidak konsisten berhubungan langsung dengan variabel kinerja tenaga operasional (Y).

\section{DAFTAR PUSTAKA}

Adlin. 2002. Kecerdasan Spiritual dan Kecerdasan Abritasi Diantara Agama dan Semiotika. http://www.paramartha.com, 12 Januari 2013
Agustian, Ary Ginanjar. 2001. Rahasia Sukses Membangun Kecerdasan Emosi dan Spiritual (ESQ). Jakarta: Arga Wijaya Persada

Anastasi, A. dan S. Urbina. 1997. Tes Psikologi (Psychological Testing). Jakarta: PT. Prehanllindo

As'ad, Mohammad. 1995. Psikologi Industri. Yogyakarta: Liberty

2001. Psikologi Industri. Yogyakarta: Liberty

Ashmos, D. dan D. Duchon. 2000. Spirituality at Work: A Conceptualization and Measure, Journal of Management Inguiry, Vo.8, No.2, pp.134-45

Azwar. 1997. Reliabilitas dan Validitas. Yogyakarta: Liberty

Behling, O. 1998. Employee Selection : Will Intelligence and Conscientiousness Do The Job?, The Academy of Management Executive, 12(1): 77-86

Berman, M. Developing SQ (Spiritual Intelligence) Throught ELT, http://www.eltnesletter.com, 12 Juni 2005

Bernardin, J. 1993. The Function of The Executive. Cambridge: Ma. Research of Harvard University

Biberma, J. dan M. Whittey. 1997. A Postmodern Spiritual Future For Work, Journal of Organizational Change Management, Vo. 10, No.2, pp.30-188

Boyatzis, R, E, Ron, S. 2001.Unleashing the Power of Self Directed Learning. USA: Case Western Reserve University, Cleveland, Ohio

Carruso, D, R. 1999. Applying The Ability Model Of Emotional Intelligence To The World of Work, http://cjwolfe.com/article.doc, 15 Oktober 2005 
Andi Prasetiawan

Chakraborty, S. K. dan D. Chakraborty. 2004. The Transformed Leader and Spiritual Psychology: A Few Insight, Journal of Organizational Change Management, Vol.17, No.2, pp.184210

Chermiss, C. 1998. Working With Emotional Intelligence, The Consortium For Research On Emotional Intelligence in Organizations. New Jersey: Rugrets University

Clifford, P. McCue dan A. Glanakis Gerasmus. 1997. The Relationship Between Job Satisfaction and Performance The Case of Local Government Finance of in Ohio, Public Productivity and Management Review, Vo.21, No.2, p.170- 191

Cooper Dr. dan C.W. Emory. 1995.Metode Penelitian Bisnis, Jilid.1, ed.5. Jakarta: Erlangga

Cooper, R, K. 2002. Executive EQ: Kecerdasan Emosi Dalam Kepemimpinan dan Organisasi. Jakarta: PT. Gramedia Pustaka Utama

Dessler, G. 1997. Manajemen Sumber Daya Manusia, Alih bahasa : Benyamin Molan. Jakarta: PT. Prenhallindo

Eckersley, R. 2000. Spirituality, Progress, Meaning, and Values, Paper Presented 3rd Annual Conference on Spirituality, Leadership, and Management, Ballarat, 4 December

Eysenck, H. J. dan L. Kamin. 1981. Intelligence: The Batle For The Mind. London dan Sydney : Pan Book 2002. Tes IQ Anda. Bandung: CV. Pionir Jaya

Goleman, D. 2000. Kecerdasan Emosi: Mengapa Emotional Intelligence Lebih Tinggi Daripada IQ, Alih Bahasa: T. Hermay. Jakarta: PT. Gramedia Pustaka Utama
2001. Emotional Intelligence

Untuk Mencapai Puncak Prestasi. Alih bahasa: Alex Tri K.W. Jakarta PT. Gramedia Pustaka Utama

Gordon, E. 2004. EQ dan Kesuksesan Kerja, Focus-online, http://www.epsikologi. om, 12 Desember 2004

Habibah, Siti. 2001. Meningkatkan Kinerja Melalui Mekanisme 360 Derajat, Telaah Bisnis, Vol.2, No.1.p.27-37

Hadi, Sutrisno. 2001. Metodologi Reset II. Yogyakarta: Fakultas Psikologi Universitas Gadjah Mada

Hair, J, F, et al. 1998. Multivariate Data Analysis. New Jersey : Prentice Hall

Hoffman, E. 2002. Psychological Testing At Work. New York : Mc Graw Hill

Hunter, J, E. dan F. L. Schmidt. 1996. Intelligence and Job Performance: Economic nd Social Implications, Psychology, Public, Policy, and Law, No.2, pp447-472

Idrus, Muhammad. 2002. Kecerdasan Spiritual Mahasiswa Yogyakarta. Psikologi Phronesis, Jurnal Ilmiah dan Terapan, Vo.4, No.8, Desember 2002

Imam, G. 2001. Aplikasi Analisis Multivariat Dengan Program SPSS. Semarang: Badan Penerbitan UNDIP

2005. Aplikasi Analisis Multivariat Dengan Program SPSS. Semarang : Badan Penerbitan UNDIP

Ivancevich, J, M. 2001. Human Resource Management, 8th Edition. New York: McGraw Hill

Joseph, G. 1978. Interpreting Psychological Test Data, Vol.1. New York VNR

Kale, S. H. dan S. Shrivastava. 2003. The Ennegram Syestem For Enhancing Workplace Spirituality, Journal of Management Development, Vol.22, No.4, pp.308-328 
Martin, Anthony Dio. 2000. Aplikasi EQ Based HR Management System, Majalah Manajemen, No.148, Desember

Mathis, R. L. dan Jackson. 2002. Manajemen Sumber Daya Manusia, Jilid 1 dan 2. Alih bahasa : Bayu Brawira. Jakarta: Salemba Empat

McCormic, D. W. 1994. Spirituality and Management, Journal Of Managerial Psychology, Vol. 9, pp.5-8

Meyer, J. 2000. EQ dan Kesuksesan Kerja, http://www.e-psikologi.com, 12 Desember 2004

Mitroff, L. I. dan E. A. Denton. 1999. A Study of Spiritualty in The Work Place, Sloan Management Review, Vol.40, No.4, pp.83-92

Moustafa, K, S, dan T. R. Miller. 2003. Too Intelligent For The Job? The Validity of Upper-Limit Cognitive Ability Test Scores In Selection, Sam Advanced Management Journal, Vol.68

Mudali. 2002. Quote : How High Is Yous Spiritual Intelligence? http://www.eng.usf.edu/gopalakr/artcl es/spiritual.html, 15 Januari 2013

Munir, Ningky. 2000. Spiritualitas dan Kinerja, Majalah Manajemen, Vol.124, Juli 2000

Munzert, A.W. 2003. Tes IQ. Jakarta: Kentindo Publisher

Nggermanto, Agus. 2002. Quantum Quotient (Kecerdasan Quantum): Cara Tepat Melejitkan IQ, EQ, dan SQ Secara Harmonis. Bandung: Nuansa

Nurhayati, Siti Fatimah. 2000. Kontribusi Sumber Daya Manusia Terhadap Kinerja Perusahaan: Masihkah Diperlukan, Telaah Bisnis, Vol.1, No, 1 , Juli

Panggabean, Mutiara S. 2002. Pengaruh Keadilan Dalam Penggajian dan Perilaku Individu Terhadap Kinerja Dosen Perguruan Tinggi Swasta, Kajian Bisnis STIE Widya Wiwaha, No.26, Mei-Agustus
Patton, P. 1998. Kecerdasan Emosional di Tempat Kerja, Alih Bahasa: Zaini Dahlan. Jakarta: Pustaka Delaprata

Purba, Ahmad. 1999. Emotional Intelligence, Seri Ayah Bunda, 26 Juli-8 Agustus. Jakarta: Dian Raya

Ravianto. 1988. Production of Management. Jakarta: LSIUP

Ree, M, J, Earles, J, Teachout, M. S. 1994. Predicting Job Performance : Not Much More Than G, Journal of Applied Psychology, Vol.79, No.4, p.518-524

Riggio, R. E. 2000. Introduction To Industrial/Organizational Psychology, Third Edition. New Jersey: Prentice Hall

Robbins, S. P. 1996. Perilaku Organisasi. Jakarta: PT. Prehallindo

Sala, F. 2004. Do Programs Designed to Increase Emotional Intelligence at Work, Emotional Intelligence Consortium Research Journal, Boston

Schultz, D. P. dan S. E. Schultz. 1994. Psychology and Work Today, An Introduction To Industrial and Organizational Psychology. Sixth Edition, Mac

Setyawan, Dani. 2004. Analisis Pengaruh Kepemimpinan $Q$ (IQ, EQ, $S Q)$ Terhadap Komitmen Organisasional Karyawan, Skripsi, Universitas Katolik Soegijapranata, Semarang

Simamora, H. 1995. Manajemen Sumber Daya Manusia. Yogyakarta: Badan Penerbit YKPN

Sugiono. 1999. Metodologi Penelitian Bisnis. Alfabeta: Bandung

Suhariadi, Fendy. 2002. Pengaruh Inteligensi dan Motivasi Terhadap Semangat Penyempurnaan Dalam Membentuk Perilaku Produktif Efisien. Anima: Indonesia Psikologi Jurnal, Vol.17, No.4, Juli 2002, p.346 
Andi Prasetiawan

Sumediyani, Maria. 2002. Kecerdasan Spiritual dan Problema Bangsa Ini, www.google.com, 12 Juni 2005

Suryabrata, Sumadi. 1998. Pembimbing Ke Psikodiagnostik II. Yogyakarta : Rake Sarasin

Wiamiharja, Sutardjo A. 2003. Keeratan Hubungan Antara Kecerdasan, Kemauan dan Prestasi Kerja, Jurnal Psikologi, Vol.11, No1, Maret 2003

Widiantoro. 2001. Menciptakan Eustress Di Tempat Kerja: Usaha meningkatkan Kinerja Karyawan, Ventura, Vol.4, No.2 September

Wiersma, M. L. 2002. The Influence of Spiritual "Meaning-Making" On Career Behaviour, Journal of Management Development, Vo.21, No.7, pp.497-520

Winardi. 1996. Perilaku Konsumen. Bandung

Yuninigsih. 2002. Membangun Komitmen dan Menciptakan Kinerja Sumber Daya Manusia Untuk Memperoleh Keberhasilan Perusahaan, Fokus Ekonomi Vol.1 No.1 April 2002

Zohar, D. Marshal I. 2001. The Ultimate Intelligence. Bandung: Mizam Media Utama

\begin{tabular}{lrr} 
2000. & SQ & (Spiritual \\
\hline Intelligence): & The & Ultimate \\
Intelligence. & London: & Blomsburry \\
Publishing & &
\end{tabular}

